\title{
Sulphoglycolysis in Escherichia coli K-12 closes a gap in the biogeochemical sulphur cycle
}

Karin Denger ${ }^{1}$, Michael Weiss ${ }^{2}$, Ann-Katrin Felux ${ }^{2}$, Alexander Schneider ${ }^{3}$, Christoph Mayer ${ }^{3}$, Dieter Spiteller ${ }^{1}$, Thomas Huhn $^{4}$, Alasdair M. Cook ${ }^{1}$ \& David Schleheck ${ }^{1}$

Sulphoquinovose (SQ, 6 deoxy 6 sulphoglucose) has been known for 50 years as the polar headgroup of the plant sulpholipid ${ }^{1,2}$ in the photosynthetic membranes of all higher plants, mosses, ferns, algae and most photosynthetic bacteria ${ }^{3}$. It is also found in some non photosynthetic bacteria ${ }^{4}$, and $S Q$ is part of the surface layer of some Archaea ${ }^{5}$. The estimated annual production of $S Q^{4}$ is $10,000,000,000$ tonnes (10 petagrams), thus it comprises a major portion of the organo sulphur in nature, where SQ is degraded by bacteria ${ }^{6,7}$. However, despite evidence for at least three different degradative pathways in bacteria ${ }^{68}$, no enzymic reaction or gene in any pathway has been defined, although a sulphoglycolytic pathway has been proposed ${ }^{7}$. Here we show that Escherichia coli $\mathrm{K} 12$, the most widely studied prokaryotic model organism, performs sulphoglycolysis, in addi tion to standard glycolysis. SQ is catabolised through four newly discovered reactions that we established using purified, heterolo gously expressed enzymes: SQ isomerase, 6 deoxy 6 sulphofructose (SF) kinase, 6 deoxy 6 sulphofructose 1 phosphate (SFP) aldolase, and 3 sulpholactaldehyde (SLA) reductase. The enzymes are encoded in a ten gene cluster, which probably also encodes regulation, trans port and degradation of the whole sulpholipid; the gene duster is present in almost all $(>91 \%)$ available $E$. coligenomes, and is wide spread in Enterobacteriaceae. The pathway yields dihydroxyacetone phosphate (DHAP), which powers energy conservation and growth of $E$. coli, and the sulphonate product 2,3 dihydroxypropane 1 sulphonate (DHPS), which is excreted. DHPS is mineralized by other bacteria, thus closing the sulphur cycle within a bacterial community.

Recent work showed that environmental isolates of Klebsiella spp. (Enterobacteriaceae) convert SQ quantitatively to DHPS ${ }^{7.8}$, and we pro posed that utilization of SQ might be a property of Enterobacteriaceae. We found that fourgenome sequenced E. coli K 12 substrains (BW25113, DH1, MG1655 and W3100), after subculturing, grew with SQ within 1 to 3 days. We chose to work (largely) with the fastest growing sub strain, MG1655. The organism used SQ as a sole source of carbon and energy with a molar growth yield of $3 \mathrm{~g}$ of protein per mol of SQ carbon, whereas glucose gave approximately $6 \mathrm{~g}$ of protein per mol of carbon; the latter value represented mass balance of glucose carbon as biomass and $\mathrm{CO}_{2}$ (ref. 9). However, approximately $1 \mathrm{~mol}$ of DHPS per mol of SQ was released into the growth medium (Fig. 1a), as observed with Klebsiella oxytoca ${ }^{8}$. Thus, there was complete mass balance for carbon and for sulphur from SQ. The growth rate with SQ was $0.13 \mathrm{~h}^{1}\left(05 \mathrm{~h}^{1}\right.$ with glucose), and the specific degradation rate for SQ in vivo was $120 \mathrm{mU}$ per $\mathrm{mg}$ of protein $\left(1 \mathrm{mU} 1 \mathrm{nmol} \mathrm{min}{ }^{1}\right)$. We concluded that $\mathrm{SQ}$ is metabolized to a $\mathrm{C}_{3}$ sulphonate, which is excreted as DHPS, and that the remainder of the molecule is used for growth (Fig. 2a).

The out grown culture was filter sterilized and inoculated with Cupriavidus pinatubonensis JMP134, which can utilize DHPS for growth ${ }^{10}$, but cannot utilize $S^{8}$. C. pinatubonensis grew with the DHPS formed from SQ by $E$. coli, and released its sulphonate sulphur quantitatively as sulphate (Fig. 1b) using a pathway described elsewhere ${ }^{10}$. We thus demonstrated mineralization of SQ in a laboratory model system.
Proteins from whole cells of $E$. coli $\mathrm{K} 12$ grown with glucose or SQ were subjected to two dimensional polyacrylamide gel electropho resis (2D PAGE) (Extended Data Fig. 1) and examined by peptide fingerprinting mass spectrometry (PF MS) (Extended Data Table 1). The immediately relevant, apparently SQ inducible proteins (see Extended Data Fig. 1 and Extended Data Table 1) were attributed to b3878 (also known as yihQ (b numbers are locus tags); predicted to be an $\alpha$ glucosidase), b3879 (also known as yihR; predicted to be an epimerase), b3880 (yihS; predicted to be an isomerase), b3881 (yihT; predicted to be an aldolase) and b3882 (yih $U$; predicted to be an $\mathrm{NAD}^{+} / \mathrm{NADH}$ linked dehydrogenase/reductase). Transcriptional analyses for the gene cluster b3879 b3882, as well as for b3883 (also known as yihV; predicted to be a sugar kinase), confirmed a strong inducible transcription during
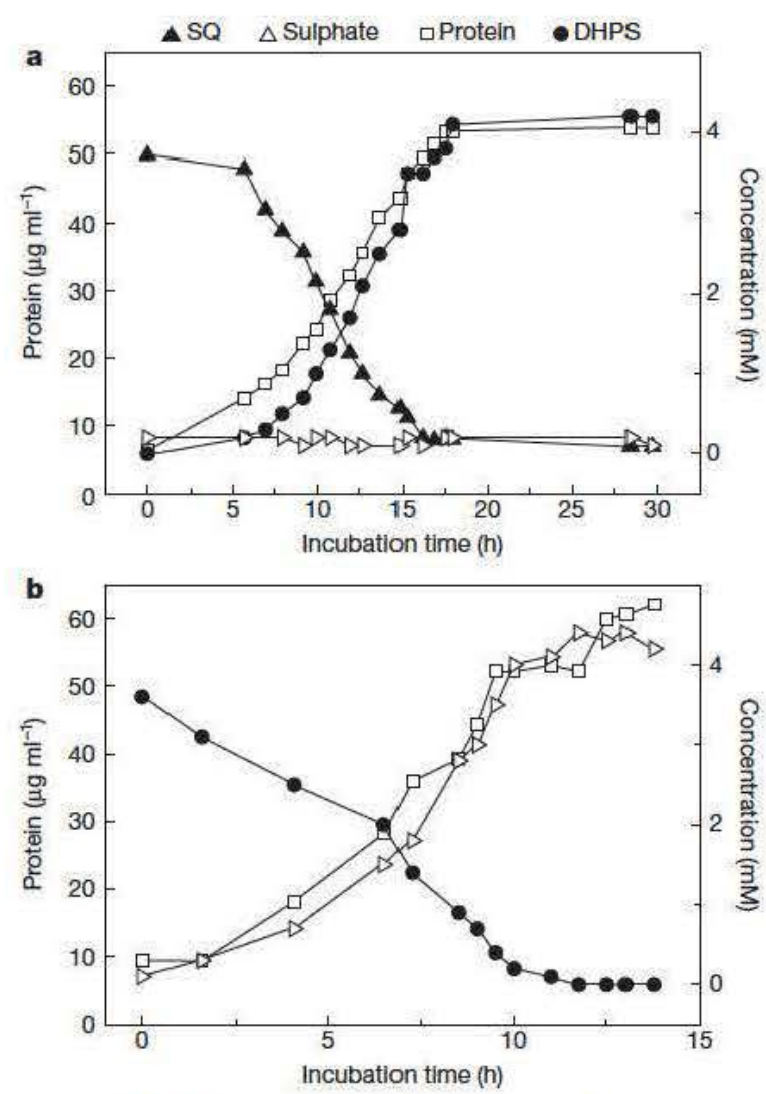

Figure 1 Complete degradation of sulphoquinovose during growth. a, Growth of $E$. coli K 12 substrain MG1655 with SQ and excretion of 2,3 dihydroxypropane 1 sulphonate (DHPS). b, Growth of $C$. pinatubonensis JMP134 with the DHPS formed from SQ by E. coli. Data from representative growth experiments $(n=3)$ are shown. To allow a compact graph, sulphate release and not total sulphate is shown. 


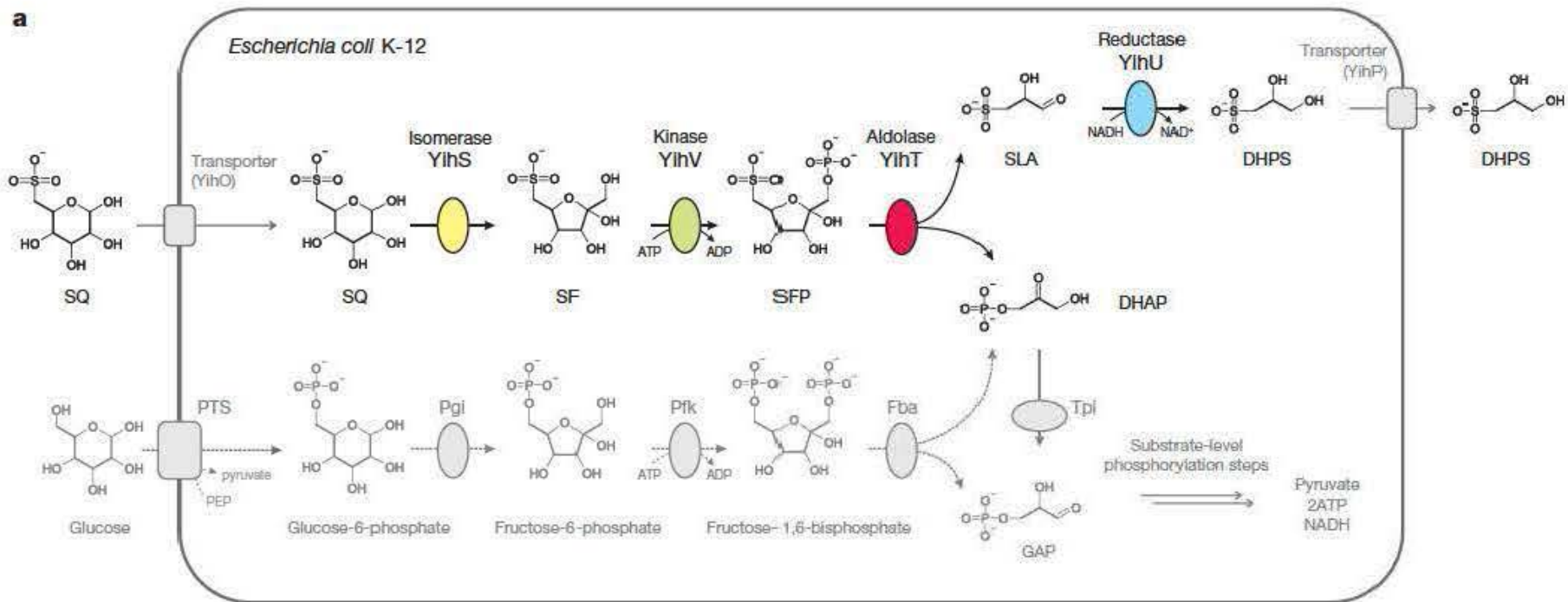

b

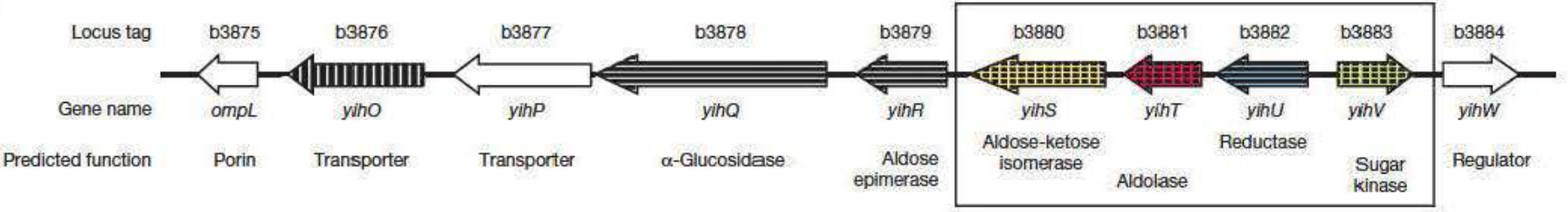

Figure 2 The four core enzyme reactions of sulphoglycolysis, with transport, and the corresponding genes in a ten gene cluster in $E$. coli K 12. a, $S Q$ is metabolized by four enzymes (shown in colour) to a $C_{3}$ sulphonate, DHPS, which is excreted, and the remainder of the molecule is used for growth. For comparison, the analogous enzyme reactions for the catabolism of (unsubstituted) glucose through the glycolytic pathway in E. coli are also shown (dashed arrows). Fba, fructose bisphosphate aldolase; GAP, glyceraldehyde 3 phosphate; Pfk, phosphofructokinase; Pgi, phosphoglucose isomerase; PTS, phosphotransferase system permease;

growth with $S Q$, but not during growth with glucose (Extended Data Fig. 2). Furthermore, single gene knockouts (in substrain BW25113 (ref. 11)) in genes b3876 (also known as yihO; predicted to be a major facilitator superfamily (MFS) type transporter), b3880, b3881 and b3883 did not grow with SQ, which confirmed and expanded on the proteo mic and transcriptional data (Fig. 2b).

We thus identified a gene cluster in E. coli $\mathrm{K} 12$ that contained SQ inducible, essential genes for catabolism of SQ, but we still did not know which pathway was involved. A sulphoglycolytic pathway would involve a hypothetical 3 sulpholactaldehyde (SLA) reductase to yield DHPS in the final reaction (apart from export) (Figs 1a and 2a), whereas a hypothetical SQ dehydrogenase as the first reaction would lead into hypothetical Entner Doudoroff type or pentose phosphate type path ways, or another novel pathway. An SLA reductase was detected (assayed as DHPS oxidation) in cell free extracts of SQ grown substrain MG1655 at a specific activity of $420 \mathrm{mU}$ per $\mathrm{mg}$ of protein, which exceeds the specific degradation rate for SQ in vivo and, thus, was sufficient to explain growth. This enzyme activity was not detected in extracts of glucose grown cells. Thus the enzyme was confirmed to be inducible, and it was specific for $\mathrm{NAD}^{+}$; $\mathrm{NADP}^{+}$was not a substrate. Further more, SQ did not lead to reduction of $\mathrm{NAD}^{+}$or of $\mathrm{NADP}^{+}$in the extracts of SQ or glucose grown cells, hence, hypothetical SQ dehy drogenase was not detectable. These data led us to predict the sulpho glycolytic pathway depicted in Fig. 2a, including the requirement for sulphonate import and export across the cell membrane ${ }^{12}{ }^{14}$.

The four predicted core enzymes of the pathway (Fig. 2a) were heter ologously expressed and purified as His tagged proteins, b3880 (putative isomerase), b3883 (putative sugar kinase), b3881 (putative aldolase) and b3882 (putative reductase) (Extended Data Fig. 3). Protein b3882 was shown to encode SLA reductase. First, we partially purified and
Tpi, triose phosphate isomerase. b, The EcoGene E. coli website (http:// www.EcoGene.org) uses the abbreviation yih for most of these genes; we have retained this nomenclature. Vertical stripes, genes confirmed as being essential for growth with SQ by mutational analysis; horizontal stripes, genes confirmed as being inducible for growth with SQ by proteomic and/or transcriptional analyses; box framed genes, genes encoding the four core enzymes of the pathway (shown in a) that were subject of heterologous expression, purification and functional characterization.

identified (PF MS) the wild type enzyme in cell free extracts of sub strain MG1655 (see above), and second, we examined the recombinant protein (see below). In both cases we identified that b3882 represents an SLA reductase; the enzyme showed no activity with 4 hydroxybutyrate ${ }^{15}$.

The heterologously expressed and purified putative isomerase (b3880) caused about one fourth of the SQ in the reaction mixture to dis appear, as observed by high pressure liquid chromatography mass spec trometry (HPLC MS), and a new peak was formed that eluted with shorter retention time, but exhibited the same relative mass $\left(M_{\mathrm{r}} \quad 244\right.$ Dalton ( $\mathrm{Da})$; observed as a quasi molecular ion in the negative ion mode ([M H] ) at a mass to chargeratio $(\mathrm{m} / \mathrm{z})$ of 243 ) (Fig. 3a, b). The new peak was confirmed to represent 6 deoxy 6 sulphofructose (SF), as proposed elsewhere 7 , by the HPLC separation pattern (Extended Data Fig. 4), by the matching exact mass of the [M H] ion (Extended Data Fig. 4), and by its MS MS fragmentation pattern (Extended Data Fig. 5). Thus we confirmed that $\mathrm{b} 3880$ catalysed the SQ isomerase reaction.

The reaction mixture was augmented with ATP and the putative sugar kinase (b3883). The peaks of SQ and SF partially disappeared and a new peak was formed (Fig. 3c). This new peak was confirmed to represent 6 deoxy 6 sulphofructose 1 phosphate (SFP), as proposed elsewhere ${ }^{7}$, by the matching exact mass of the $[\mathrm{M} \mathrm{H}]$ ion (observed mass, $322.9877 \mathrm{Da}$; theoretical mass of $\mathrm{C}_{6} \mathrm{H}_{12} \mathrm{O}_{11} \mathrm{PS}$, $322.9843 \mathrm{Da}$ ) and by its fragmentation pattern (Extended Data Fig. 6). HPLC con firmed that ATP disappeared and ADP was formed during the reac tion and, furthermore, that SFP was converted back to SF when alkaline phosphatase was added to a preparation of SFP (not shown). Thus, with b3883, we expressed an ATP dependent kinase that phosphory lated SF to SFP.

The reaction mixture was augmented with the putative aldolase (b3881). The peak for SFP partially disappeared, and two new peaks were formed 


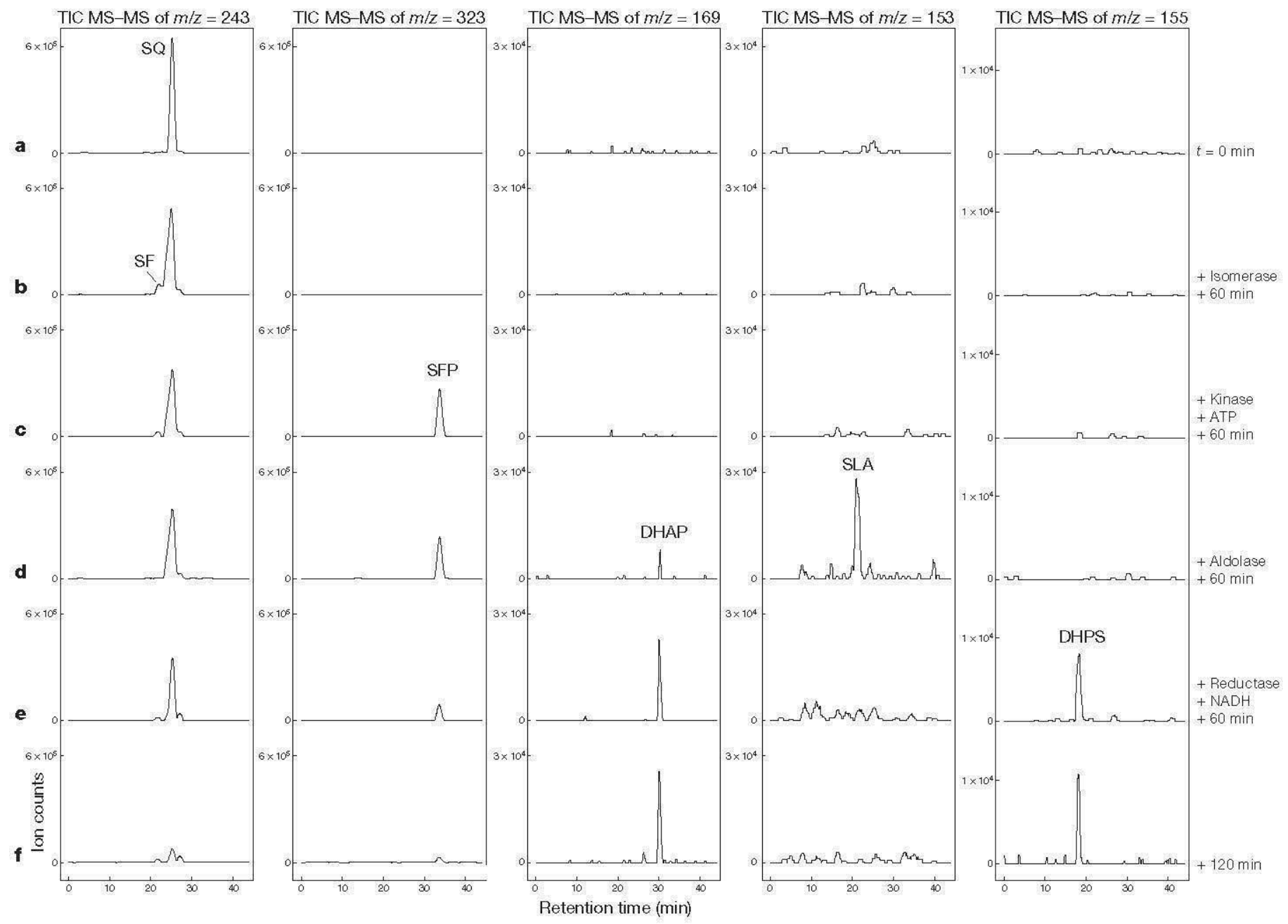

Figure 3 mllustration of the reactions of the four core enzymes of sulphoglycolysis in vitro. The transformation of SQ to SF, SFP, DHAP and SLA, and DHPS, by successive addition of recombinantly expressed pathway enzymes was followed by HPLC ESI MS. a, Sample of SQ in reaction buffer $(t=0 \mathrm{~min})$. b, Sample after addition of isomerase $(\mathrm{b} 3880)(t=60 \mathrm{~min})$. c, Sample after addition of ATP and kinase (b3883) ( $t=120 \mathrm{~min})$. d, Sample after addition of aldolase (b3881) ( $t=180 \mathrm{~min})$. e, Sample after addition of

(Fig. 3d). The first new peak was identified to represent DHAP, as pro posed elsewhere ${ }^{7}$, with an authentic DHAP standard. The second new peak was confirmed to represent SLA, as proposed elsewhere ${ }^{7}$, by the matching mass of the [M H] ion $\left(M_{r} \quad 154 \mathrm{Da}\right.$; observed as [M H] ion at $m / z \quad 153$ ) and by its fragmentation pattern (Extended Data Fig. 7); the same peak was observed when we used recombinant SLA reductase in reverse to oxidize DHPS to SLA (see above). Thus, with b3881, we expressed an aldolase that cleaved SFP into DHAP and SLA. The SFP turnover was incomplete (Fig. $3 \mathrm{~d}$ ); the equilibrium of the corresponding enzyme reaction in glycolysis (fructose 1,6 bisphosphate aldolase) lies far to the left ${ }^{16}$, that is, hardly any products are formed.

However, when NADH and the recombinant SLA reductase (b3882) were added, the peak for SFP was further diminished, as was the peak for $\mathrm{SQ}$, and that for the aldolase reaction product DHAP was further increased (Fig. 3e). In addition, the peak for SLA had disappeared, and the peak for the anticipated sulphonate product, DHPS, was formed (Fig. $3 e$ and Extended Data Fig. 7). After an extended incubation of the four enzyme reaction (see Fig. 3e, f), the peaks for SQ and SFP had almost completely disappeared, and the peaks for DHAP and DHPS had further increased.

Together, the results show that the SQ pathway in E. coli K 12 (Fig. 2a) does not involve a desulphonation reaction and that no substrate level phosphorylation of the sulphonated $\mathrm{C}_{3}$ intermediate occurs, which has
NADH and reductase (b3882) $(t=240 \mathrm{~min})$. f, Sample after extended incubation of the four enzyme reaction $(t=360 \mathrm{~min})$. The total ion chromatograms (TICs) recorded in the negative ion mode from the MS MS fragmentation of the quasi molecular ions [M H] of SQ and SF, SFP, DHAP, SLA and DHPS, from a representative experiment $(n=5)$ are shown. For representative MS MS fragmentation patterns of the [M H] ions of SQ and SF, SFP, and SLA and DHPS, see Extended Data Figs 5, 6 and 7, respectively.

been used previously ${ }^{7}$ as a default hypothesis. Furthermore, we deduce that there are ten genes in the gene cluster (Fig. 2b). The core pathway comprises a SQ transporter (for example, b3876, YihO), SQ isomerase (b3880, YihS), SF kinase (b3883, YihV), SFP aldolase (b3881, YihT), SLA reductase (b3882, YihU) and a DHPS exporter (for example, b3877, YihP), which could be under the putative control of repressor b3884 (YihW). We propose a sulpholipid porin (b3875, OmpL), a sulpholi pid $\propto$ glucosidase (b3878, YihQ), and an epimerase (b3879, YihR) to funnel other SQ derivatives into the pathway; for example, the whole sulpholipid (see Extended Data Fig. 8).

The gene cluster is found in at least $1,009(>91 \%)$ of the 1,110 genome sequences of commensal E. coli, as well as pathogenic E. coli (for example, EHEC) strains, that were available in November 2013 (finished and draft genome sequences) in the Integrated Microbial Genomes (IMG) and Human Microbiome Project (HMP) databases (that is, gene clus ters with syntenic yihTUVW and collinear homologues of $y$ ihSRQPO and $o m p L$ in variable order). Hence, the gene cluster is a feature of the core genome of $E$. coli species. It can also be found in a wide range of other Enterobacteriaceae (for example, Chronobacter sakazakii ATCC BAA 894, Klebsiella oxytoca 10 5242, Pantoea ananatis LMG 20103 and Salmonella enterica LT2). We therefore suspect that the pathway has a significant role in bacteria in the alimentary tract of all omnivores and herbivores, that the pathway occurs in bacteria in excrement from 
these animals, and that it occurs in plant pathogens, which would explain part of the widespread occurrence of microbial degradation observed $^{6}$.

SQ is produced in large amounts in nature and thus represents a significant proportion of the organic sulphur cycle ${ }^{4}$, and it is degraded in similar amounts by both bacteria ${ }^{68}$ and algae $^{17}$, or it would accu mulate in the environment. We see here that the Enterobacteriaceae use one pathway (Fig. 2a) to initiate degradation of SQ, and that a com munity is required for complete degradation (Fig. 1b) ${ }^{8}$. This covers a variety of habitats, but we know that other pathways exist. A previous paper $^{7}$ presented evidence for SQ dehydrogenase, which we also observe in our SQ using strain of Pseudomonas putida (A. K.F. unpublished observations). Notably, another group ${ }^{6}$ reported complete SQ degra dation, including desulphonation, in a single organism; however, this organism has been lost ${ }^{18}$.

In summary, we have established that sulphoglycolysis, which was named but not defined in a previous report ${ }^{19}$, converts SQ to DHPS in the most widely studied prokaryotic model organism, E. coli K 12, rep resenting many Enterobacteriaceae (Fig. 2a). We have identified a gene cluster in E. coli $\mathrm{K} 12$ (Fig. 2b) that encodes the pathway. The core pathway, for SQ, involves four newly discovered enzymes, two newly identified transporters and three newly characterized intermediates (Fig. 2a, b). We know that the pathway is regulated (Extended Data Figs 1 and 2) and we suspect that it includes the degradation of the whole sulpholipid (Extended Data Fig. 8). The pathway represents a substantial part of the biogeochemical sulphur cycle, and the pathway is likely to have a significant role in bacteria in the alimentary tract of all omnivores and herbivores, and in plant pathogens. We and others ${ }^{6} 8$ anticipate other degradative pathways for SQ in nature; for example, in bacteria of all marine, freshwater and terrestrial habitats where SQ is produced and degraded. We now provide the tools to elucidate these degradative pathways.

\section{METHODS SUMMARY}

SQ and DHPS were synthesized chemically and identified by NMR and mass spectrometry ${ }^{8.10}$. Cultivation, preparation of cell free extracts, enzyme purification, 2D $P A G E$ and $P F$ MS, RNA preparation and polymerase chain reaction with reverse transcription (RT PCR), and expression and purification of His tagged proteins, are described in the online Methods. SQ, SF, SFP, SLA, DHAP and DHPS were separated using hydrophilic interaction liquid chromatography (HILIC) ${ }^{8}$ and detected by an evaporative light scattering detector (ELSD) ${ }^{8}$ or electrospray ion ization (ESI) time of flight (TOF) MS or ESI iontrap MS (see Methods). The enzyme reaction mixture (Fig. 3 ) was $3 \mathrm{mMSQ}$ in $50 \mathrm{mM}$ ammonium acetate buffer (pH 8.7), and $8 \mathrm{mM} \mathrm{ATP}, 0.5 \mathrm{mM} \mathrm{MgCl}_{2}$ and $8 \mathrm{mM} \mathrm{NADH}$ supplemented with the corresponding enzymes (each $50 \mu \mathrm{g} \mathrm{ml}{ }^{\mathrm{l}}$ ).

1. Benson, A. A. The plant sulfolipid. Adv. Lipid Res. 1, 387394 (1963).
2. Benning, $C$. Questions remaining in sulfolipid biosynthesis: a historical perspective. Photosynth. Res. 92, 199203 (2007).

3. Benning, C. Biosynthesis and function of the sulfolipid sulfoquinovosyl diacylglycerol. Annu. Rev. Plant Physiol. Plant Mol. Biol. 49, 5375 (1998).

4. Harwood, J. L. \& Nicholls, R. G. The plant sulpholipid a major component of the sulphur cycle. Biochem. Soc. Trans. 7, 440447 (1979).

5. Meyer, B. H. et al. Sulfoquinovose synthase an important enzyme in the $\mathrm{N}$ glycosylation pathway of Sulfolobus acidocaldarius. Mol. Microbiol. 82, 11501163 (2011).

6. Martelli,H.L. Oxidation of sulphoniccompounds by aquatic bacteria isolated from rivers of the Amazon region. Nature 216, 12381239 (1967).

7. Roy, A. B., Hewlins, M. J. E., Ellis, A. J., Harwood, J. L. \& White, G. F. Glycolytic breakdown of sulfoquinovose in bacteria: a missing link in the sulfur cycle. Appl Environ. Microbiol. 69, 64346441 (2003).

8. Denger, K., Huhn, T., Hollemeyer, K., Schleheck, D. \& Cook, A. M. Sulfoquinovose degraded by pure cultures of bacteria with release of $C_{3}$ organosulfonates: complete degradation in two member communities. FEMAS Microbiol. Lett 328, 3945 (2012).

9. Cook, A. M. Biodegradation of s triazine xenobiotics. FEMS Microbiol Rev. 46, $93116(1987)$.

10. Mayer, J.et al. 2,3 Dihydroxypropane 1 sulfonate degraded by Cupriavidus pinatubonensis JMP134: purification of dihydroxypropanesulfonate 3 dehydrogenase. Microbiology 156, 1556 1564(2010).

11. Baba, T.efal. Construction of Escherichia coli $\mathrm{K} 12$ in frame, single gene knockout mutants: the Keio collection. Mol. Syst Biol. 2, 2006.0008 (2006).

12. Graham, D. E., Xu, H. \& White, R. H. Identification of coenzyme M biosynthetic phosphosulfolactate synthase: a new family of sulfonate biosynthesizing enzymes. J. Biol. Chem. 277, 1342113429 (2002).

13. Mampel, J. et al. A novel outer membrane anion channel (porin) as part of the putatively two component transport system for $\rho$ toluenesulfonate in Comamonas testosteroni T 2. Biochem. J. 383, 9199 (2004).

14. Mayer, J. \& Cook, A. M. Homotaurine metabolized to 3 sulfopropanoate in Cupriavidus necator $\mathrm{H} 16$ : enzymes and genes in a patchwork pathway. J. Bacteriof. 191,60526058 (2009).

15. Saito, N. ef af. Metabolite profiling reveals $Y$ ihU as a novel hydroxybutyrate dehydrogenase for alternative succinic semialdehyde metabolism in Escherichia colf. J. Biol. Chem. 284, 1644216451 (2009).

16. Cornish Bowden, A. Thermodynamic aspects of glycolysis. Biochem. Educ. 9 , $133137(1981)$.

17. Sugimoto, K., Sato, N. \& Tsuzuki, M. Utilization of a chloroplast membrane sulfolipid as a major internal sulfur source for protein synthesis in the early phase of sulfur starvation in Chlamydomonas reinhardft. FEBS Lett 581, 45194522 (2007).

18. Cook, A. M. \& Denger, K. Dissimilation of the $C_{2}$ sulfonates.Arch. Microbiol. 179, 16 (2002).

19. Benson, A. A. \& Shibuya, I. Sulfocarbohydrate metabolism. Fed. Proc. 20, 79 (1961).

Acknowledgements We thank E Deuerling for substrain MG1655, J. Klebensberger for substrain BW25113 and its knockout mutants, and K. Leitner for help with growth experiments. The work of M.W. and A. K.F. was supported by the Konstanz Research School Chemical Biology (KoRS CB), the work of C.M. by German Research Foundation (DFG) grants (MA2436/4 and SFB766/A15) and by the Baden Württemberg Stiftung (P BWS Glykol 1), and the work of D.Sc. by a DFG grant (SCHL 1936/1 1) and by the University of Konstanz and the Konstanz Young Scholar Fund.

Author Contributions K.D. carried out most of the enzymic experiments, together with M.W. and A. K.F., who carried out the heterologous expressions and RT PCR. A. K.F., A.S., C.M. and D.Sp. carried out the LC MS analyses, and T.H. the chemical syntheses and NMR. D.Sc. set up the HILIC separation and carried out the 2D PAGE, growth physiology and mutant analyses. A.M.C. and D.Sc. wrote the manuscript.

Author Information Reprints and permissions information is available at www.nature.com/reprints. The authors declare no competing financial interests. Readers are welcome to comment on the online version of the paper. Correspondence and requests for materials should be addressed to A.M.C. (alasdair.cook@uni konstanzde) or D.Sc. (david.schleheck@uni konstanz.de). 


\section{METHODS}

Chemicals. SQ and DHPS were synthesized chemically and identified by NMR and mass spectrometry as described previously ${ }^{8,10}$. Dihydroxyacetone phosphate dilithium salt, D fructose 6 phosphate disodium salt hydrate, D glucose 6 phosphate disodium salt hydrate, and $\mathrm{D}$ fructose 1,6 bisphosphate trisodium salt octahydrate were from Sigma. Other biochemicals (NADH, NADPH, $\mathrm{NAD}^{+}, \mathrm{NADP}^{+}, \mathrm{ATP}$, ADP) were purchased from Sigma, Fluka, Merck or Biomol.

Bacteria and growth conditions. Escherichia coli $\mathrm{K} 12$ substrains W3100 (DSM 5911, ATCC 27325) and DH1 (DSM 4235, ATCC 33849), and Cupriavidus pina tubonensis IMP134 (DSM 4058) ${ }^{20}$ were purchased from the Leibniz Institute DSMZ Deutsche Sammlung von Mikroorganismen und Zellkulturen GmbH. E. coli K 12 substrain MG1655 (DSM 18039) was a gift from E. Deuerling, and E. coli $\mathrm{K} 12$ substrain BW25113 and its single gene knockouts from the E. coli Keio Knockout Collection ${ }^{11}$ were a gift from $J$. Klebensberger. The growth medium was a phosphate buffered mineral salts medium ${ }^{21}(\mathrm{pH} 7.2)$ with SQ or glucose as the sole carbon sources. Cultures were inoculated (1\%) with pre culture grown with the same substrate, and grown aerobically at $30^{\circ} \mathrm{C}$. Cultures in $3 \mathrm{ml}$ volume were grown in screw cap tubes $(30 \mathrm{ml})$ in a roller, and cultures in $50 \mathrm{ml}$ or $200 \mathrm{ml}$ volume in capped Erlenmeyer flasks ( 0.3 or 1.0 litre volume, respectively) on a horizontal shaker; for the Erlenmeyer flask cultures, $0.8 \mathrm{ml}$ samples were taken at intervals to determine optical density (attenuance $D$ at $580 \mathrm{~nm} ; D_{580 \mathrm{~nm}}$ ) and substrate and product concentrations (HILIC HPLC, see below). For the growth experiments to demonstrate mineralization of SQ (see Fig. 1), E. coli K 12 substrain MG1655 was grown with SQ ( $4 \mathrm{mM} ; 50 \mathrm{ml}$ scale), and after growth had been completed, the cellular biomass was removed from the culture fluid by centrifugation $(20,000 \mathrm{~g}, 30$ $\min , 4^{\circ} \mathrm{C}$ ) followed by filter sterilization (pore size, $0.2 \mu \mathrm{m}$ ). The culture fluid was then inoculated with $C$. pinatubonensis JMP134. During the growth experiments, samples were taken at intervals to monitor the growth $\left(D_{580 \mathrm{~nm}}\right)$ and to determine total protein, substrate, and product concentrations (see below). All growth experi ments were replicated twice $\left(\begin{array}{ll}n & 3\end{array}\right)$.

Preparation of crude extract, soluble fraction and enzyme enrichment. E. col cells from growth experiments with $S Q$ or glucose were collected at an $D_{580 \mathrm{~nm}}$ of approximately 0.4 by centrifugation $\left(20,000 \mathrm{~g}, 15 \mathrm{~min}, 4^{\circ} \mathrm{C}\right)$ and disrupted by three passages through a chilled French pressure cell (140 megapascals (MPa); Aminco) in the presence of DNase $\left(25 \mu \mathrm{g} \mathrm{ml}{ }^{1}\right)$. Cell debris was removed by centrifugation $\left(11,000 \mathrm{~g}, 5 \mathrm{~min}, 4^{\circ} \mathrm{C}\right)$ and the membrane fragments collected by ultracentrifuga tion $\left(70,000 \mathrm{~g}, 1 \mathrm{~h}, 4^{\circ} \mathrm{C}\right)$; the supernatant was called the soluble fraction. For enzyme enrichment, soluble fraction was loaded onto an anion exchange chromatography column (MonoQ HR 10/10 column, Pharmacia) equilibrated with $20 \mathrm{mM}$ Tris/ $\mathrm{H}_{2} \mathrm{SO}_{4}$ buffer, $\mathrm{pH} 9.0$, at a flow rate of $1 \mathrm{ml} \mathrm{min}{ }^{1}$, and bound proteins eluted by a linear $\mathrm{Na}_{2} \mathrm{SO}_{4}$ gradient (from $0 \mathrm{M}$ to $0.2 \mathrm{M}$ in $45 \mathrm{~min}$, and to $0.5 \mathrm{M}$ in $10 \mathrm{~min}$ ) and fractions ( $2 \mathrm{ml}$ ) collected; the SLA reductase activity eluted at about $0.12 \mathrm{MNa}_{2} \mathrm{SO}_{4}$. Two dimensional gel electrophoresis and peptide fingerprinting mass spec trometry. 2D PAGE and PF MS were carried out according to our previously published protocols ${ }^{22}$. In brief, soluble protein fractions from $E$. coli cells grown with SQ or glucose (see above) were desalted (PD 10 Desalting Columns, GE Healthcare Life Sciences) and precipitated by addition of acetone (four volumes $100 \%$ acetone, $-20^{\circ} \mathrm{C}$, overnight); each $1 \mathrm{mg}$ of precipitated protein was solubi lised in rehydration buffer $(300 \mu \mathrm{l})$ and loaded onto isoelectric focusing (IEF) strips (BioRad ReadyStrip IPG system) overnight; IEF involved a voltage ramp to $10,000 \mathrm{~V}$ during $3 \mathrm{~h}$, and a total focusing of $40,000 \mathrm{Volt}$ hours (Vh); the strips were equilibrated in SDS equilibration buffers I and II (with DTT and iodoaceta mide, respectively) and placed onto SDS PAGE gels using an overlay of SDS gel buffer solidified with agarose ( $0.5 \%$ ); SDS PAGE gels contained $12 \%$ polyacryl amide (no stacking gel), and were stained with Coomassie brilliant blue R 250 (ref. 23). Stained protein spots of interest were excised from gels and submitted to PF MS at the Proteomics Facility of the University of Konstanz to identify the corresponding genes; the MASCOT engine (Matrix Science) was used to match each peptide fingerprint against a local database of all predicted protein sequences of the annotated E. coli K 12 substrain MG1655 genome (IMG version 201108 16). Total RNA preparation and $\mathrm{PCR}$ with reverse transcription. RNA preparation and RT PCR were carried out according to our previously published protocols ${ }^{24}$ In brief, cells were grown in the appropriate selective medium $(3 \mathrm{ml})$ and collected in the mid exponential growth phase $\left(D_{580 \mathrm{~nm}} \approx 0.3\right)$; the cell pellets were stored at $-20^{\circ} \mathrm{C}$ in RNAlater RNA stabilization solution (Applied Biosystems); total RNA was prepared using the E.ZN.A. Bacterial RNA Kit (Omega Bio Tek) following the manufacturer's instructions; the RNA preparation $(40 \mu \mathrm{l})$ was treated with RNase free DNase ( 2 units, $30 \mathrm{~min}, 37^{\circ} \mathrm{C}$ ) (Fermentas). For complementary DNA (cDNA) synthesis, the Maxima reverse transcriptase (Fermentas) was used follow ing the manufacturer's instructions; the reactions contained $0.2 \mu \mathrm{g}$ total RNA and 20 pmol sequence specific primer (see below). PCR reactions ( $20 \mu \mathrm{l}$ volume) were carried out using Taq DNA polymerase (Fermentas) and the manufacturer's stan dard reaction mixture (including $2.5 \mathrm{mMMgCl}_{2}$ ); $\mathrm{CDNA}$ from reverse transcription reactions was used as template ( $2 \mu \mathrm{l}$ of reverse transcription reaction mixture), or genomic DNA (4 ng DNA) for PCR positive controls, or non reverse transcribed total RNA $(2 \mu \mathrm{l})$ for the confirmation of an absence of DNA impurities in the RNA preparations.

Heterologous expression and purification of His tagged proteins. Heterolo gous expression of candidate genes and purification of the recombinant proteins were carried out according to our previously published protocol ${ }^{25}$. In brief, chro mosomal DNA was isolated using the Illustra bacteria genomicPrep Mini Spin Kit (GE Healthcare) and the target genes amplified by PCR using Phusion HF DNA Polymerase (Finnzymes) and the primer pairs given below. The PCR conditions were 30 cycles of $18 \mathrm{~s}$ denaturation at $98^{\circ} \mathrm{C}, 20 \mathrm{~s}$ annealing at $58^{\circ} \mathrm{C}$, and $60 \mathrm{~s}$ elon gation at $72{ }^{\circ} \mathrm{C}$ for gene $b 3880$, or $45 \mathrm{~s}$ elongation at $72^{\circ} \mathrm{C}$ for genes $\mathrm{b} 3881, \mathrm{~b} 3882$, and $\mathrm{b} 3883$. The $\mathrm{PCR}$ products were then separated by agarose gel electrophoresis, excised, and purified using the QIAquick gel extraction kit (Qiagen), and ligated into the amino terminal $\mathrm{His}_{6}$ tag expression vector pET100 (Invitrogen); correct integration of the inserts was confirmed by sequencing (GATC Biotech). For expres sion, BL21 Star (DE3) OneShot E. coli cells (Invitrogen) were transformed with the constructs and grown at $37^{\circ} \mathrm{C}$ in lysogeny broth medium containing $100 \mathrm{mg} 1{ }^{1}$ ampicillin; at an $D_{580 \mathrm{~nm}} \approx 0.6$, the cultures were induced by addition of $0.5 \mathrm{mM}$ IPTG (isopropyl $\beta \mathrm{D}$ thiogalactoside), and the cells grown for additional 4 to $5 \mathrm{~h}$ at $20^{\circ} \mathrm{C}$, collected by centrifugation $\left(15,000 \mathrm{~g}, 20 \mathrm{~min}, 4^{\circ} \mathrm{C}\right)$, and stored frozen $\left(-20^{\circ} \mathrm{C}\right)$. Cells were resuspended in buffer $\mathrm{A}(20 \mathrm{mM}$ Tris $\mathrm{HCl}, \mathrm{pH} 8.0,100 \mathrm{mM}$ $\mathrm{KCl}$ ) that contained $50 \mu \mathrm{g} \mathrm{ml}{ }^{~} \mathrm{DNase} \mathrm{I}$, and disrupted by four passages through a pre cooled French pressure cell ( $140 \mathrm{MPa})$. The cell extracts were centrifuged $(15,000 \mathrm{~g}$, $\left.10 \mathrm{~min}, 4^{\circ} \mathrm{C}\right)$ and ultracentrifuged $\left(70,000 \mathrm{~g}, 1 \mathrm{~h}, 4^{\circ} \mathrm{C}\right)$, and the soluble protein fractions loaded onto $1 \mathrm{ml} \mathrm{Ni}{ }^{2+}$ chelating Agarose affinity columns (Macherey Nagel) pre equilibrated with buffer A (see above). After a washing step ( $30 \mathrm{mM}$ imidazole in buffer $\mathrm{A}$ ), the His tagged proteins were eluted $(200 \mathrm{mM}$ imidazole in buffer A), concentrated in a Vivaspin concentrator (Sartorius), and, after addition of $30 \%$ glycerol $(\mathrm{v} / \mathrm{v})$, stored in aliquots at $-20^{\circ} \mathrm{C}$

Enzyme assays. SLA reductase activity was assayed photometrically at $365 \mathrm{~nm}$ in $1 \mathrm{ml}$ cuvettes in $50 \mathrm{mM}$ Tris $\mathrm{HCl}$ buffer, $\mathrm{pH} 9.0$, with $1 \mathrm{mM} \mathrm{NAD}^{+}$and $5 \mathrm{mM}$ DHPS as substrates. The reaction was started with the addition of protein $(0.01$ $0.1 \mathrm{mg} \mathrm{ml}^{1}$ ) and the reduction of $\mathrm{NAD}^{+}$was recorded. Enzyme assays with recom binant proteins (each $50 \mu \mathrm{g}$ protein $\mathrm{ml}^{1}{ }^{\mathbf{1}}$ ) for analysis by HIIIC HPLC were carried out in $1 \mathrm{ml}$ volume in $50 \mathrm{mM}$ ammonium acetate buffer, $\mathrm{pH} 8.7$, stirred at room temperature (approximately $2023^{\circ} \mathrm{C}$ ); samples were taken at intervals, for which the reactions were stopped by addition of $30 \%$ acetonitrile. SQ $(3 \mathrm{mM})$ and recom binant isomerase were incubated for $60 \mathrm{~min}$, after which ATP $(8 \mathrm{mM}), \mathrm{MgCl}_{2}$ $(0.5 \mathrm{mM})$ and recombinant kinase were added. After additional $60 \mathrm{~min}$, recombi nant aldolase was added, and after another $60 \mathrm{~min} \mathrm{NADH}(8 \mathrm{mM})$ and the recom binant reductase.

Analytical methods. Total protein was determined according to a protocol based on a method reported previously ${ }^{26}$, and soluble protein was determined by protein dye binding ${ }^{27}$, each using bovine serum albumin (BSA) as the standard. Sulphate release during growth was quantified turbidimetrically ${ }^{28}$ as a suspension of $\mathrm{BaSO}_{4}$. For HPLC ESI MS MS, an Agilent 1100 HPLC system fitted with a ZIC HILIC column $(5 \mu \mathrm{m}, 200 \AA, 150 \times 4.6 \mathrm{~mm}$; Merck) was connected to an LCQ ion trap mass spectrometer (Thermofisher). The HPLC conditions for the LCQ ion trap were: from $90 \% \mathrm{~B}$ to $65 \% \mathrm{~B}$ in $25 \mathrm{~min}, 65 \% \mathrm{~B}$ for $10 \mathrm{~min}$, in $0.5 \mathrm{~min}$ back to $90 \% \mathrm{~B}$ $90 \% \mathrm{~B}$ column equilibration for $9.5 \mathrm{~min}$; solvent $\mathrm{A}, 90 \% 0.1 \mathrm{M} \mathrm{NH}_{4} \mathrm{Ac}, 10 \%$ ace tonitrile; solvent $\mathrm{B}$, acetonitrile; flow rate, $0.75 \mathrm{ml} \mathrm{min}{ }^{1}$. The mass spectrometer was run in ESI negative mode. The retention times and ESI MS MS fragmenta tion patterns of the analytes were observed as follows: SQ retention time, $25.4 \mathrm{~min}$ SQ ESI MS $m / z$ (per cent base peak) 243 (100); SQ ESI MS MS of [M H] 243 243 (4), 225 (11), $207(34), 183(100), 153(54), 143(1), 123$ (16), 101 (8), 81 (6). SF retention time, $21.9 \mathrm{~min}$; SF ESI MS, 243 (100); SF ESI MS MS of [M H] 243 $243(1), 225$ (37), 207 (38), 183 (21), 153 (100), $143(3), 123(24), 101$ (13), 81 (5). SFP retention time, $33.4 \mathrm{~min}$; SFP ESI MS, $323(100)$; SFP ESI MS MS of [M H] 323: 305 (34), 287 (3), 233 (2), 225 (100), 207 (32), 153 (4). SLA retention time, 21 min; SLA ESI MS, 153 (100); SLA ESI MS MS of [M H] 153: $153(9)$ 81 (100), 71 (18). DHPS retention time, $18 \mathrm{~min}$; DHPS ESI MS, 155 (100), 95 (4); DHPS ESI MS MS of [M H] 155: $155(100), 137(18), 95(40)$. DHAP retention time, $30.2 \mathrm{~min}$; DHAP ESI MS: $169(100)$ ); DHAP ESI MS MS of [M H] 169: 169 (2), 125 (2), 97 (100). HPLC for ESI TOF MS (MicrO TOF II, Bruker) involved the same column and gradient system, but a different gradient program (from $90 \%$ $\mathrm{B}$ to $65 \% \mathrm{~B}$ in $20 \mathrm{~min}$, and further to $55 \% \mathrm{~B}$ in $20 \mathrm{~min}$ ), which resulted in retention times (see Extended Data Fig. 4) of $22.4 \mathrm{~min}$ for SQ, $21.8 \mathrm{~min}$ for SF, $16.3 \mathrm{~min}$ for fructose, $18.5 \mathrm{~min}$ for glucose, $35.2 \mathrm{~min}$ for fructose 6 phosphate, and $39.8 \mathrm{~min}$ for glucose 6 phosphate.

PCR primers. Primers were purchased from Microsynth (Balgach). The sequences of the primers pairs for RT PCR (see above) were (product length in bp): b3879 forward, 5' CCTTATGGCGTGGGTATTCATCC 3', b3879 reverse, 5' TTAGG 
CGGGCAACTCATAGGTTC 3' (353); b3880 forward, $5^{\prime}$ ACGCGGTGGAAG CTT'TCTTGAT 3', b3880 reverse, 5' CACGGTGGCGTTAAACAGACCT'T 3' (332); b3881 forward, $5^{\prime}$ TGTCGCCGCCGATGAGTTC 3', b3881 reverse, $5^{\prime} \mathrm{C}$ 'TTTGTAGAGGTCAGCGCCAC TGT' 3' (320); b3882 forward, 5' GGCGCAG GCCGCTAAAGA $3^{\prime}$, b3882 reverse, $5^{\prime}$ AAGATTCAGGGCTTCGCACAAAA $3{ }^{\prime}$ (439); b3883 forward, 5' GGCACGACGGCGCTAAAAA 3', b3883 reverse, 5' TGACTCCGCTAAATCCCCACTTG 3' (374); b0720 forward, 5' CGCTGGCG GCGTTCTATCA $3^{\prime}$, b0720 reverse, 5' ATTTTCAGCGCCGCTTCGTTAG 3' (403). The sequences of the primers pairs for TOPO cloning and heterologous expression (see above) were (the directional overhang is underlined): b3880 for ward, $5^{\prime}$ CACCGGAATGAAATGGTTTAACACCCTAAG 3', b3880 reverse, 5' AACCCGCACCCTATTTTCAG 3'; b3881 forward, 5' CACCATGAATAA GTACACCATCAACGACATTACG 3', b3881 reverse 5' ACCATTTCATTCC 'TTTTATCCTCATCT'T $3^{\prime}$; b3882 forward, $5^{\prime}$ CACCATGGCAGCAATCGCGT 'TTATCG $3^{\prime}$, b3882 reverse, 5' CGCGTAATGTCGTTGATGGTGTA $3^{\prime}$; b3883 forward, $5^{\prime}$ CACCATGATTCGTGTTGCTTGTGTAGGT $3^{\prime}$, b3883 reverse, $5^{\prime}$ TGAAAAT'TCCTCGAAAAACCATCA 3 '.

Genome analyses. Analysis of genomes for orthologous gene clusters was carried out through the gene cassette search and neighbourhood regions search options of the Integrated Microbial Genomes (IMG) and IMG Human Microbiome Project (IMG HMP) platforms (http://img.jgidoe.gov/). Basic sequence analyses were done using NCBI's BLAST tools (http//blastncbi.nlm.nih.gov) and the Lasergene DNAstar software package (http://www.dnastar.com).

Enzyme nomenclature. We suggest that sulpholactaldehyde reductase belongs to the NC IUBMB subgroup EC 1.1.1., with the name sulpholactaldehyde 3 reductase (systematic name 2,3 dihydroxypropane 1 sulphonate: $\mathrm{NAD}^{+} 3$ oxidoreductase). The sulphofructose kinase would then belong to EC 2.7.1., with the name sulphofruc tose 1 kinase (systematic name ATP:6 deoxy 6 sulphofructose 1 phosphotransferase) The sulphofructosephosphate aldolase would belong to EC 4.1.2., with the name sulphofructosephosphate aldolase (systematic name 6 deoxy 6 sulphofructose
1 phosphate 2 hydroxy 3 oxopropane 1 sulphonate lyase (glycerone phosphate forming)). Sulphoquinovose isomerase would belong to EC 5.3.1., with the name sulphoquinovose isomerase (systematic name 6 deoxy 6 sulphoglucose aldose ketose isomerase).

20. Sato, Y. et al. Cupriavidus pinatubonensis sp. nov. and Cupriavidus laharis sp. nov, novel hydrogen oxidizing, facultatively chemolithotrophic bacteria isolated from volcanic mudflow deposits from Mt. Pinatu bo in the Philippines. Int J. Syst Evol. Microbiol. 56,973 978 (2006).

21. Thurnheer, T., Köhler, T., Cook, A. M. \& Leisinger, T. Orthanilic acid and analogues as carbon sources for bacteria: growth physiology and enzymic desulphonation. J. Gen. Microbiol. 132, 12151220 (1986).

22. Schmidt, A., Müller, N., Schink, B. \& Schleheck, D. A proteomic view at the biochemistry of syntrophic butyrate oxidation in Syntrophomonas wolfei. PLOS ONE 8, e56905 (2013).

23. Laemmli, U. K. Cleavage of structural proteins during the assembly of the head of bacteriophage T4. Nature 227, 680685 (1970).

24. Weiss, M., Denger, K., Huhn, T. \& Schleheck, D. Two enzymes of a complete degradation pathway for linear alkylbenzenesulfonate (LAS) surfactants: 4 sulfoacetophenone Baeyer Villiger monooxygenase and 4 sulfop henylacetate esterase in Comamonas testosteroni KF 1. Appl. Environ. Microbiol. 78 $82548263(2012)$

25. Felux, A. K Denger, K Weiss, M. \& Cook, A. M \& Schleheck, D. Paracoccus denitrificans PD1222 utilizes hypotaurine via transamination followed by spontaneous desulfination to yield acetaldehyde, and finally acetate for growth. J. Bacteriol. 195, $29212930(2013)$

26. Kennedy, S. I.T.\& Fewson, C. A. Enzymes of the mandelate pathway in bacterium N.C.I.B. 8250 . Biochem. J. 107, 497506 (1968).

27. Bradford, M. M. A rapid and sensitive method for the quantitation of microgram quantities of protein utilizing the principle of protein dye binding. Anal. Biochem 72,248254 (1976).

28. Sörbo, B. Sulfate: turbidimetric and nephelometric methods. Methods Enzymol $143,36(1987)$. 


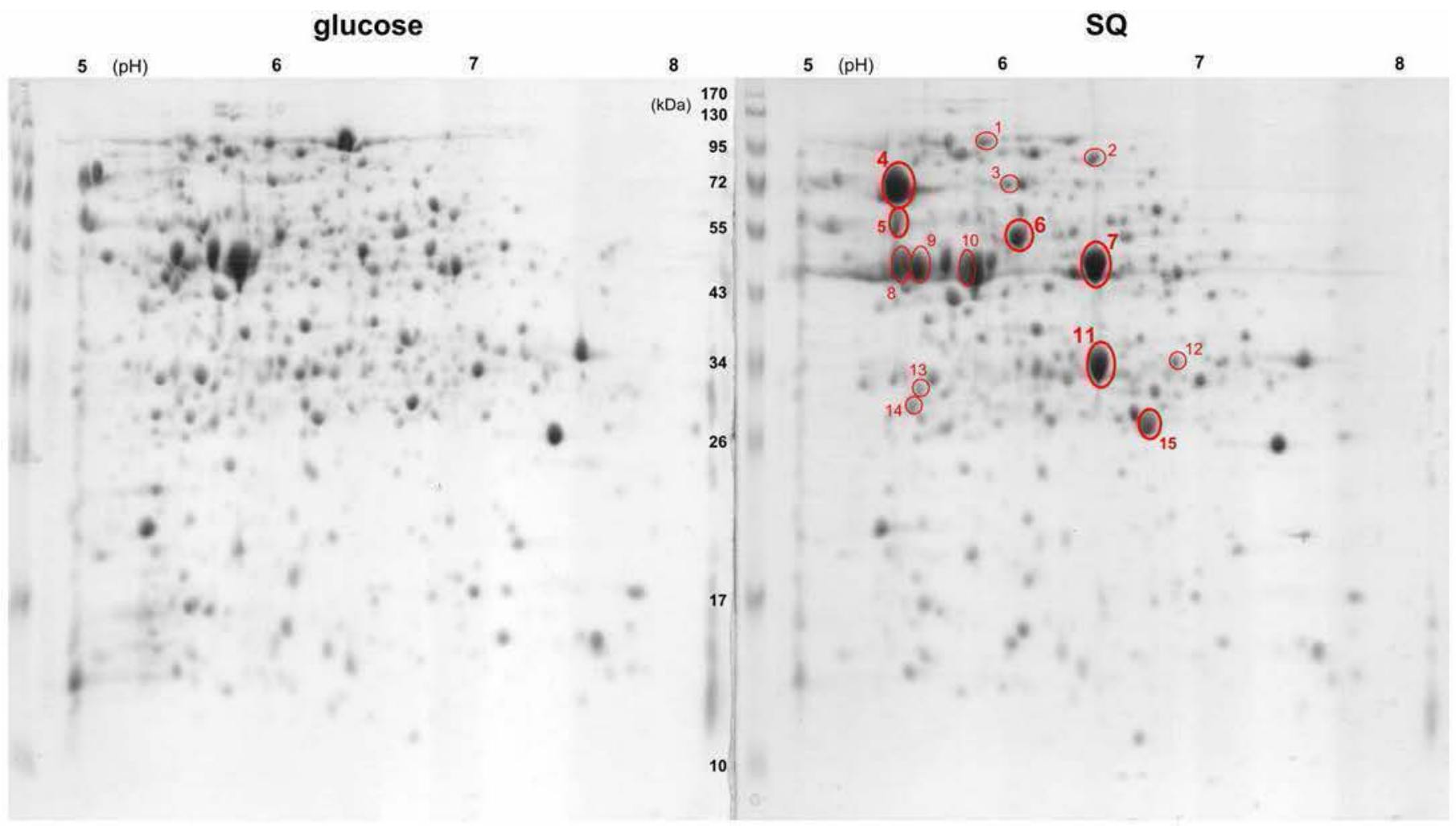

Extended Data Figure 1 | Soluble proteins in ghucose or SQ grown cells of E. coli K 12 MG 1655 separated by 2D PAGE. All prominent protein spots on the gel from SQ grown cells that suggested inducibly expressed proteins

were excised and submitted to PF MS (see Extended Data Table 1). The PF MS identifications were replicated in an independent growth experiment and gel electrophoresis run. 

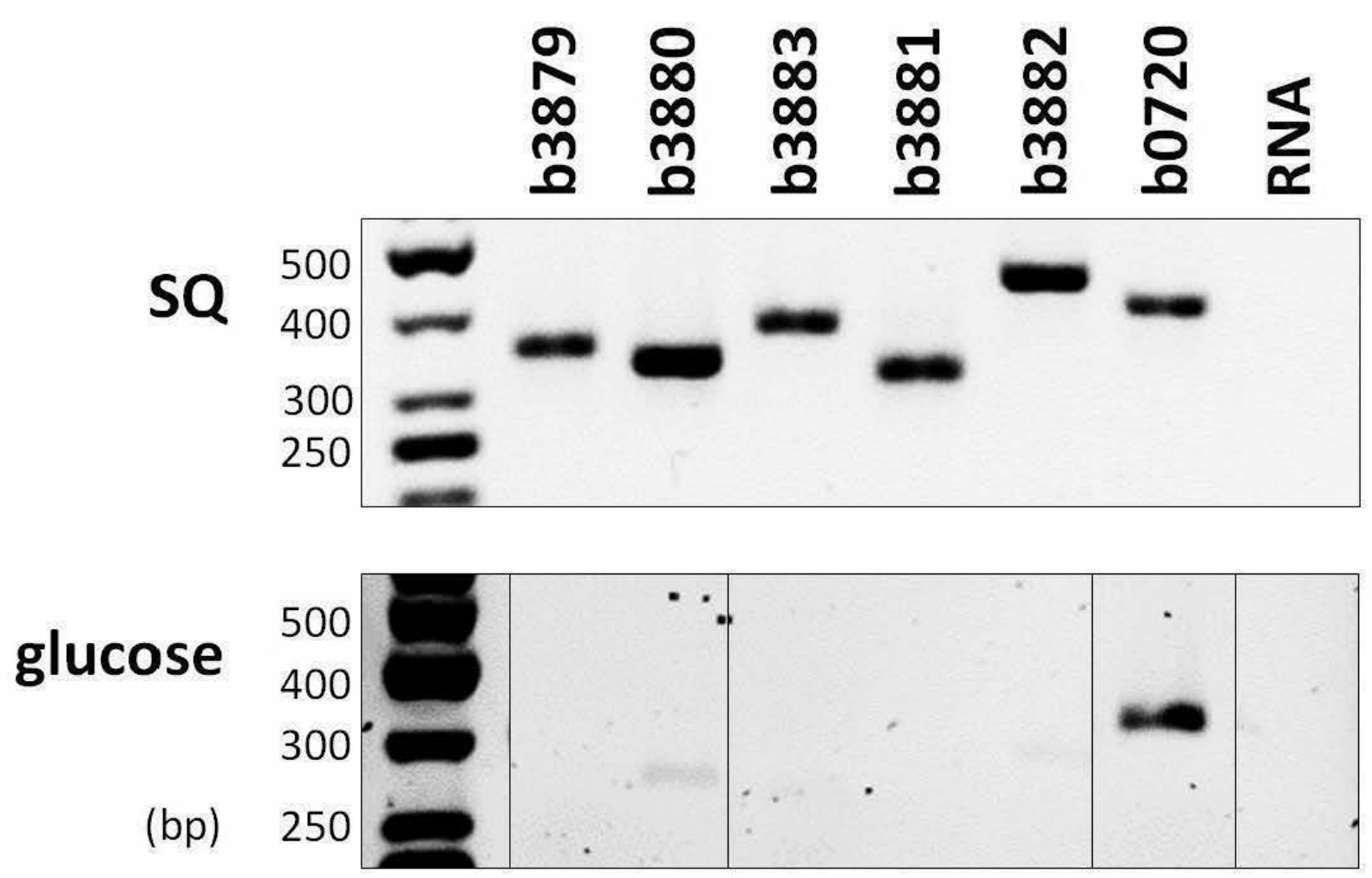

Extended Data Figure 2 $\mid$ Differential transcriptional analysis of the genes encoding the central pathway of sulphoglycolysis in E. coli K 12. RT PCR of the inducible transcription of genes b3879 (epimerase), b3880 (isomerase), b3883 (kinase), b3881 (aldolase) and b3882 (reductase) in cells grown with SQ in comparison to glucose grown cells. A positive control was a constitutively

expressed gene (b0720; glt $A$, citrate synthase), and a negative control was a PCR without reverse transcription (RNA) to confirm the absence of DNA contamination in the RNA preparations used. The results were replicated starting from an independent growth experiment. 


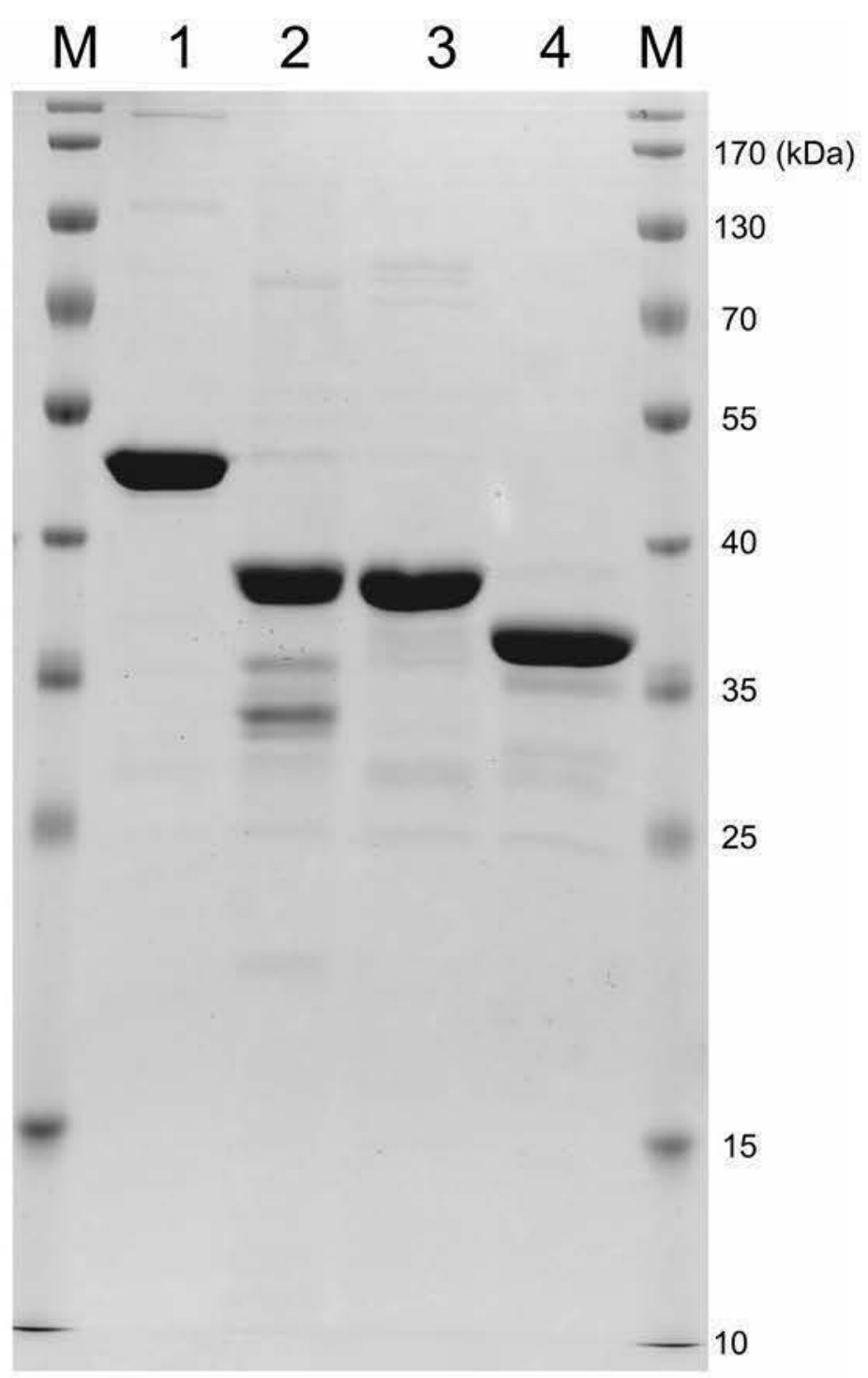

Extended Data Figure 3 Purity of heterologously expressed enzymes using SDS PAGE. M, marker proteins; 1, b3880 (isomerase); 2, b3883 (sugar kinase); $3, \mathrm{~b} 3881$ (aldolase); 4 , b3882 (reductase). A representative SDS gel is shown $\left(\begin{array}{ll}n & 2\end{array}\right)$. Each enzyme, 20 ,g. 

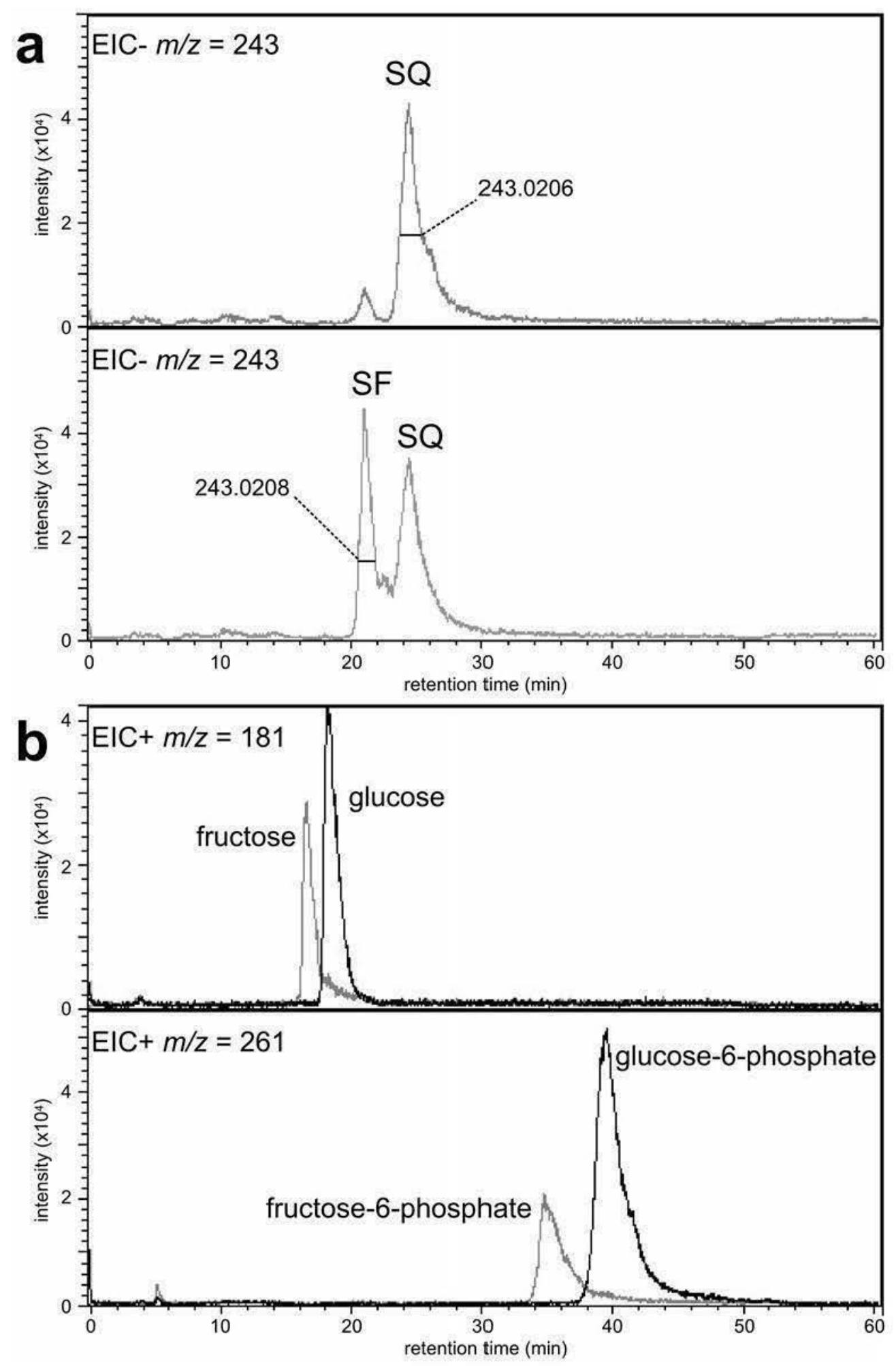

Extended Data Figure 4 Separation of SQ, SF and analogues by HILIC HPLC and detection by ESI TOF MS. a, Extracted ion

chromatogram of $S Q$ in reaction buffer before (top) and after (bottom) addition of recombinant isomerase $\mathrm{b} 3880$ to generate SF. The exact masses determined for the $[\mathrm{M} \mathrm{H}]$ ions of $\mathrm{SQ}$ and SF are indicated (in Da); the theoretical exact masses (monoisotopic masses) for the $[\mathrm{M} \mathrm{H}]$ ions of both $\mathrm{SQ}$ and $\mathrm{SF}$ (each $\mathrm{C}_{6} \mathrm{H}_{11} \mathrm{O}_{8} \mathrm{~S}$ ) is $243.0180 \mathrm{Da}$. The data from a representative experiment are shown; the results were replicated ( $n$ 3) with samples from independent enzyme reactions. $\mathbf{b}$, Samples of reference substances fructose and glucose (top), and fructose 6 phosphate and glucose 6 phosphate (bottom). The reference substances illustrate the chromatographic separation by HILIC; that is, the ketoses (for example, SF) elute before the aldoses (for example, SQ). 

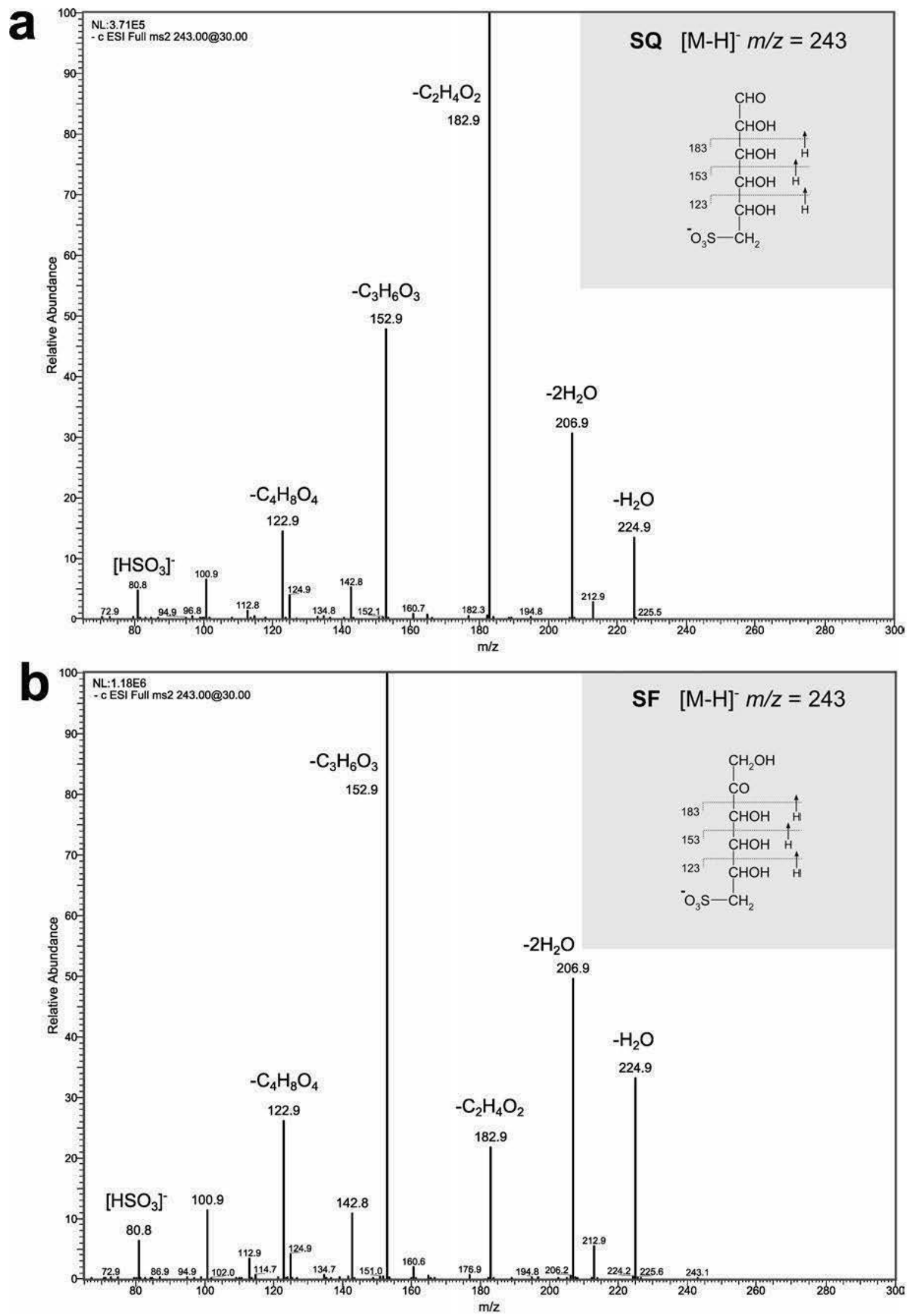

Extended Data Figure 5 |MS MS fragmentation of SQ and SF. a, Fragment ions of the $[\mathrm{M} \mathrm{H}]$ ions of SQ. b, Fragment ions of the $[\mathrm{MH}]$ ions of SF. The fragmentation pattern of both compounds, $\mathrm{SQ}$ and $\mathrm{SF}$, is dominated by the loss of water $(-18), \mathrm{C}_{2} \mathrm{H}_{4} \mathrm{O}_{2}(-60), \mathrm{C}_{3} \mathrm{H}_{6} \mathrm{O}_{3}(-90)$ and $\mathrm{C}_{4} \mathrm{H}_{8} \mathrm{O}_{4}(-120)$, and by the formation of $\mathrm{HSO}_{3}$ (81) ions. The MS MS spectra of $\mathrm{SQ}$ and SF differ in their peak heights, in particular in their base peak for $S Q(183)$ and of $\mathrm{SF}$ (153) corresponding to a preferred formation of $\mathrm{C}_{4} \mathrm{H}_{7} \mathrm{O}_{6} \mathrm{~S}$ and $\mathrm{C}_{3} \mathrm{H}_{5} \mathrm{O}_{5} \mathrm{~S}$, respectively; both fragments might be formed by McLafferty like rearrangement reactions corresponding to the different positions of the keto groups in SQ and SF. Representative data are shown ( $n$ 5; see Fig. 3 ). 


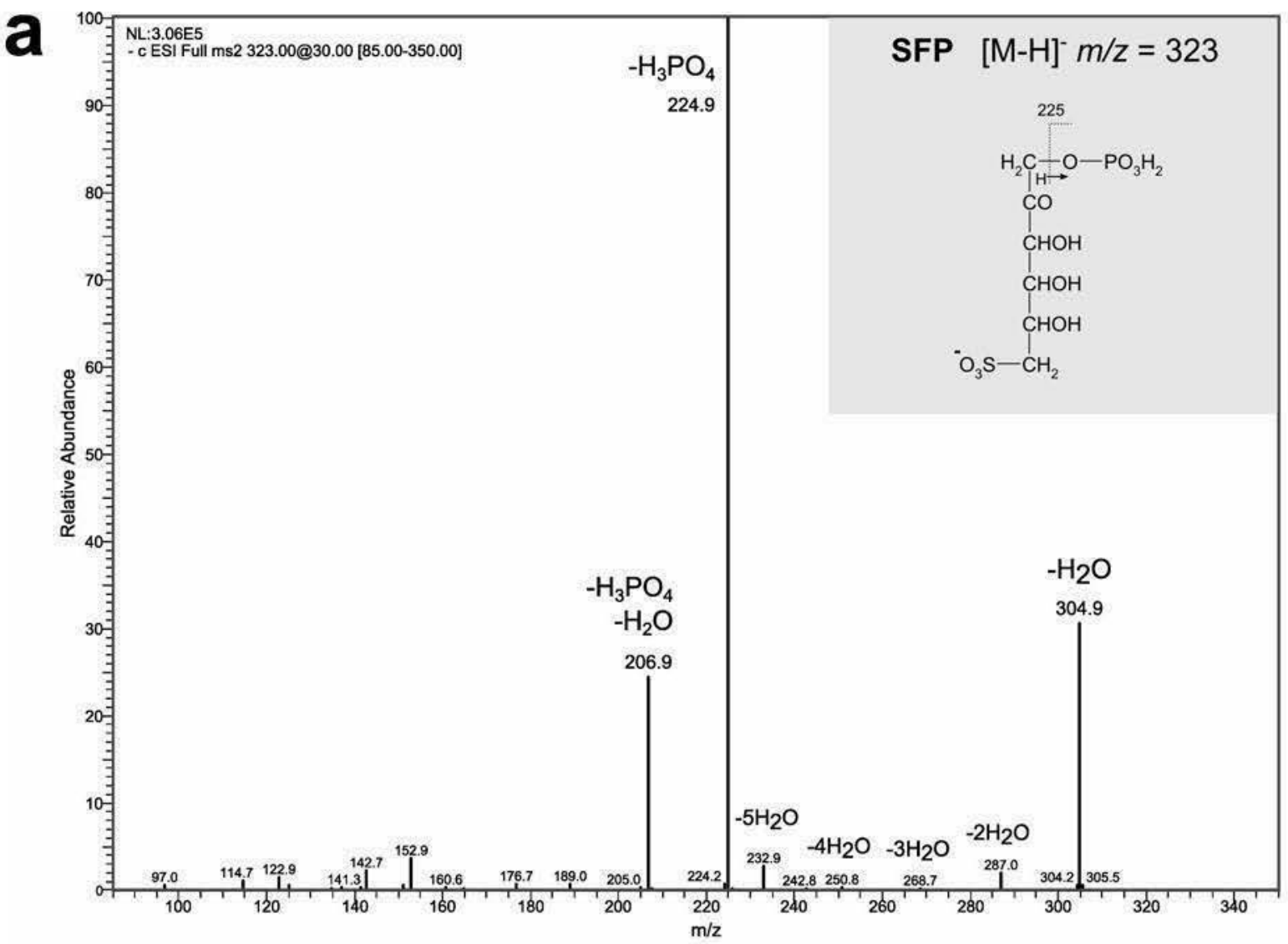

b

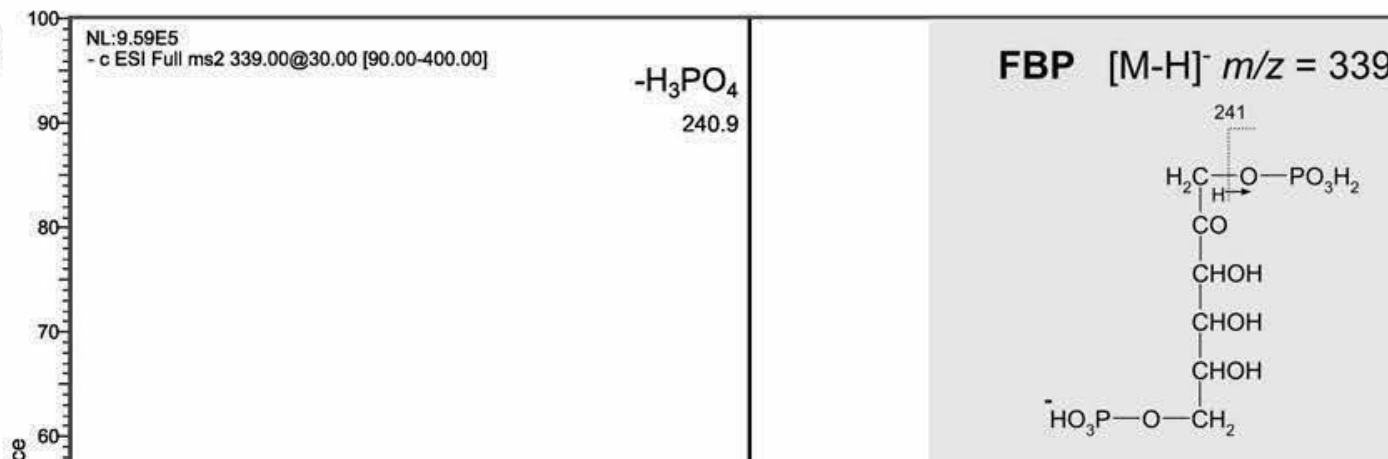

Extended Data Figure 6 $\mid$ MS MS fragmentation of SFP and FBP. a, Fragment ions of the $[\mathrm{MH}$ ] ions of SFP. b, Fragment ions of the $[\mathrm{MH}]$ ions of the analogue fructose 1,6 bisphosphate (FBP) for comparison. 

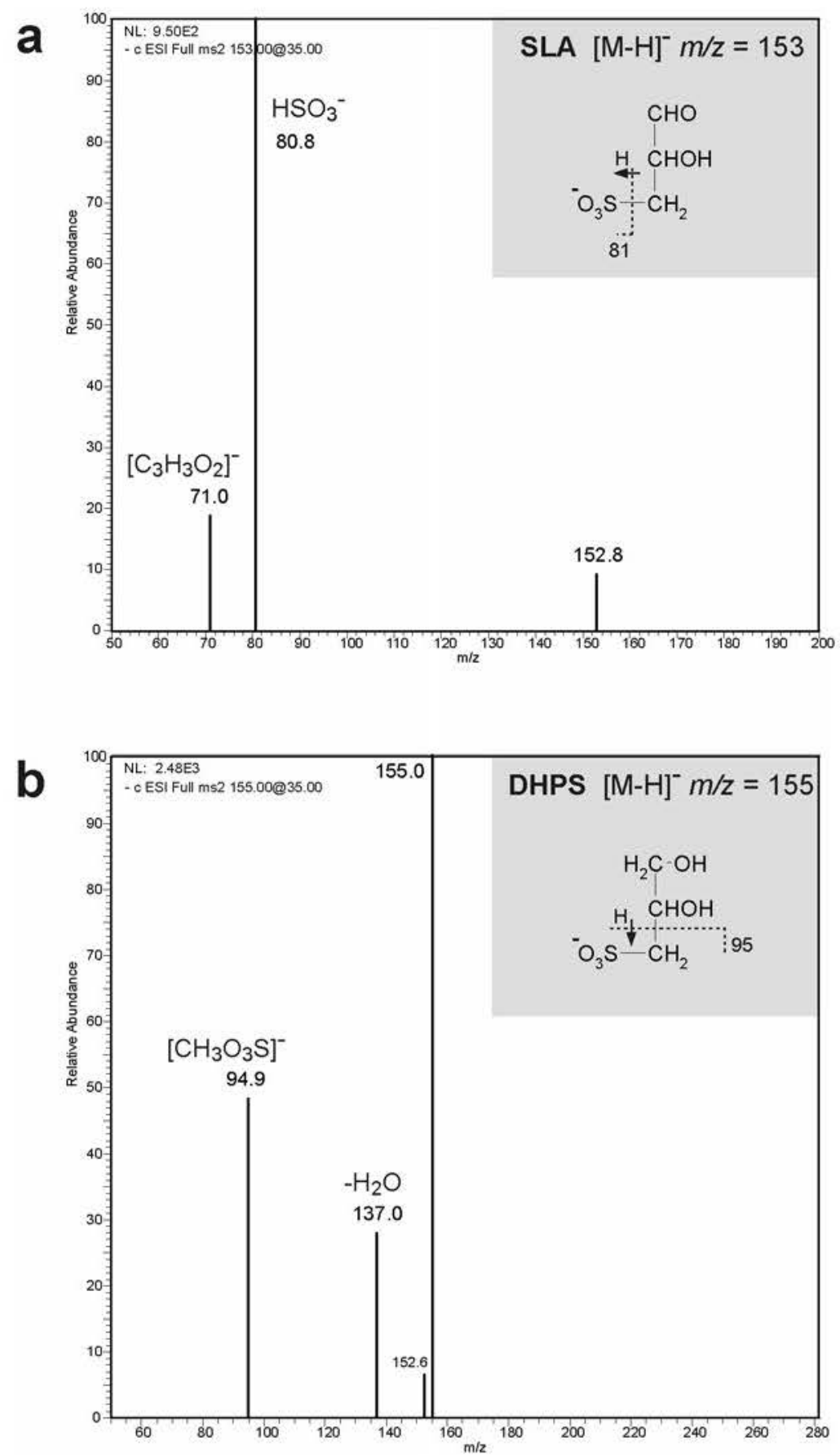

Extended Data Figure $7 \mid$ MS MS fragmentation of SLA and DHPS. a, Fragment ions of the $[\mathrm{M} \mathrm{H}]$ ions of SLA. b, Fragment ions of the $[\mathrm{M} \mathrm{H}]$ ions of DHPS. Fragmentation of SLA led to a cleavage of the carbon sulphur bond and formation of $\mathrm{HSO}_{3} \quad(81)$ and $\left[\mathrm{C}_{3} \mathrm{H}_{3} \mathrm{O}_{2}\right]$ (71) ions. The fragmentation of DHPS is characterized by an initial loss of water $(-18)$ and concomitant fragmentation of the enol (or the methylketone) to ketene $(-42)$ and formation of $\left[\mathrm{CH}_{3} \mathrm{O}_{3} \mathrm{~S}\right]$ (95) ions; the same fragmentation pattern was observed for authentic DHPS standard (not shown). Representative data are shown ( $n$ 5; see Fig. 3). 


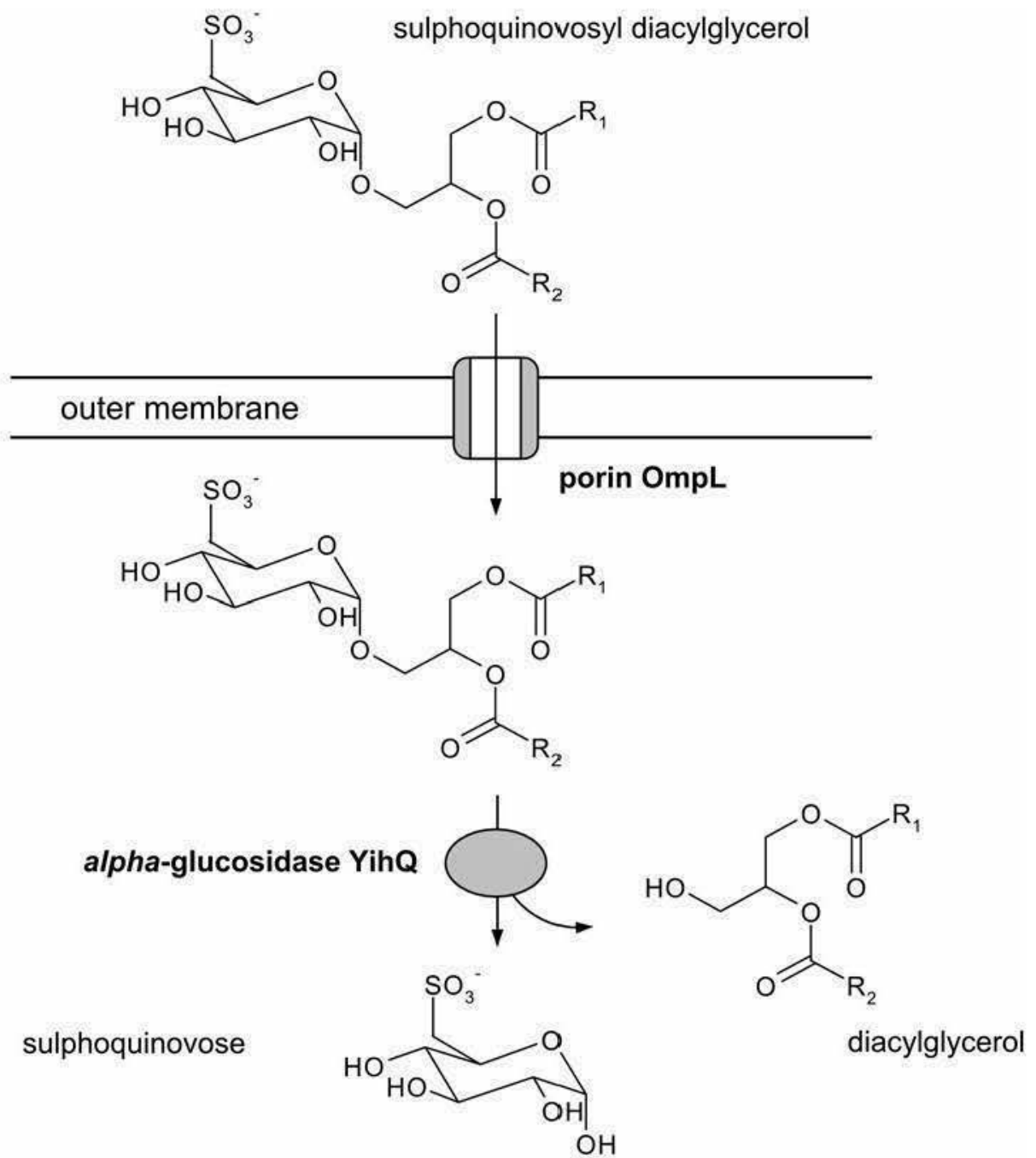

Extended Data Figure 8 | Hypothetical degradation of the sulpholipid sulphoquinovosyl diacylglycerol in $E$. coll $\mathrm{K} 12$. Presumed functions of OmpL (b3875) and YihQ (b3878); apart from OmpL, the subcellular location of this pathway is unknown. $R_{1}$ and $R_{2}$ indicate acyl chains of different length and degree of unsaturation. 
Extended Data Table 1 | Identifications by peptide fingerprinting-mass spectrometry of protein spots excised from 2D-PAGE gels of SQgrown $E$. coli cells

\begin{tabular}{|c|c|c|c|c|c|c|c|c|}
\hline \multirow{2}{*}{$\begin{array}{l}\text { Protein } \\
\text { spot } \\
\text { (no.) }\end{array}$} & \multirow{2}{*}{$\begin{array}{l}\text { Apparent } \\
\text { mass on } \\
\text { gel } \\
(\mathrm{kDa})\end{array}$} & \multirow{2}{*}{$\begin{array}{l}\text { Apparent } \\
\text { pl on gel } \\
(\mathrm{pH})\end{array}$} & \multicolumn{6}{|c|}{ PF-MS identification } \\
\hline & & & $\begin{array}{c}\text { Gene } \\
\text { (locus tag) }\end{array}$ & Annotation & $\begin{array}{l}\text { Predicted } \\
\text { mass } \\
(\mathrm{kDa})\end{array}$ & $\begin{array}{l}\text { Predicted pl } \\
\qquad(\mathrm{pH})\end{array}$ & Score & $\begin{array}{c}\text { Sequence } \\
\text { coverage } \\
(\%)\end{array}$ \\
\hline 1 & 95 & 6 & $\begin{array}{l}\text { b0114 } \\
\text { b3829 }\end{array}$ & $\begin{array}{c}\text { pyruvate dehydrogenase, decarboxylase component (aceE) } \\
\text { homocysteine transmethylase (metE) }\end{array}$ & $\begin{array}{l}99,948 \\
85,020\end{array}$ & $\begin{array}{l}5.46 \\
5.61\end{array}$ & $\begin{array}{l}999 \\
246\end{array}$ & $\begin{array}{l}54 \\
35\end{array}$ \\
\hline 2 & 80 & 6.5 & b0903 & pyruvate formate lyase (pflB) & 85,588 & 5.69 & 757 & 57 \\
\hline 3 & 70 & 6 & b2935 & transketolase, thiamine-binding $(t k t A)$ & 72,451 & 5.43 & 683 & 59 \\
\hline 4 & 70 & 5.5 & b3878 & alpha-glucosidase (yihQ) / glycosyl hydrolase family 31 & 77,853 & 5.06 & 1198 & 76 \\
\hline 5 & 55 & 5.5 & b1415 & NAD-linked aldehyde dehydrogenase (aldA) & 52,411 & 5.07 & 1475 & 70 \\
\hline 6 & 50 & 6.0 & b2095 & tagatose-1,6-bisphosphate aldolase, non-catalytic subunit (gatZ) & 47,535 & 5.50 & 1135 & 84 \\
\hline 7 & 45 & 6.5 & b3880 & aldose-ketose isomerase (yihS) & 47,687 & 5.71 & 839 & 84 \\
\hline 8 & 45 & 5.3 & $\begin{array}{l}\text { b3880 } \\
\text { b1136 } \\
\text { b4015 } \\
\text { b2942 } \\
\text { b2029 }\end{array}$ & $\begin{array}{c}\text { aldose-ketose isomerase (yihS) / D-mannose isomerase } \\
\text { NADP }^{+} \text {-linked isocitrate dehydrogenase } \\
\text { isocitrate lyase (aceA) } \\
\text { S-adenosylmethionine synthetase (metK) } \\
\text { 6-phosphogluconate dehydrogenase, decarboxylating }\end{array}$ & $\begin{array}{l}47,687 \\
46,070 \\
47,777 \\
42,153 \\
51,563\end{array}$ & $\begin{array}{l}5.71 \\
5.15 \\
5.16 \\
5.10 \\
5.06\end{array}$ & $\begin{array}{l}554 \\
410 \\
324 \\
222 \\
207\end{array}$ & $\begin{array}{l}73 \\
55 \\
36 \\
47 \\
46\end{array}$ \\
\hline 9 & 45 & 5.5 & $\begin{array}{l}\text { b4015 } \\
\text { b1136 }\end{array}$ & $\begin{array}{l}\text { isocitrate lyase }(\text { aceA) } \\
\text { isocitrate dehydrogenase, specific for NADP }\end{array}$ & $\begin{array}{l}47,777 \\
46,070\end{array}$ & $\begin{array}{l}5.15 \\
5.16\end{array}$ & $\begin{array}{c}1256 \\
108\end{array}$ & $\begin{array}{l}91 \\
13\end{array}$ \\
\hline 10 & 45 & 5.7 & $\begin{array}{l}\text { b3339 } \\
\text { b4177 } \\
\text { b1493 }\end{array}$ & $\begin{array}{l}\text { protein chain elongation factor EF-Tu } \\
\text { adenylosuccinate synthetase (purA) } \\
\text { glutamate decarboxylase ( } \operatorname{gadB})\end{array}$ & $\begin{array}{l}43,427 \\
47,543 \\
53,204\end{array}$ & $\begin{array}{l}5.30 \\
5.31 \\
5.29\end{array}$ & $\begin{array}{l}803 \\
511 \\
277\end{array}$ & $\begin{array}{l}74 \\
52 \\
48\end{array}$ \\
\hline 11 & 35 & 6.5 & b3881 & predicted aldolase (yihT) & 32,248 & 5.74 & 1487 & 92 \\
\hline 12 & 35 & 7 & $\begin{array}{l}\text { b3879 } \\
\text { b0729 }\end{array}$ & $\begin{array}{l}\text { predicted aldose-1-epimerase (yihR) } \\
\text { succinyl-CoA synthetase, alpha subunit }\end{array}$ & $\begin{array}{l}34,387 \\
30,044\end{array}$ & $\begin{array}{l}6.07 \\
6.32\end{array}$ & $\begin{array}{l}155 \\
152\end{array}$ & $\begin{array}{l}35 \\
29\end{array}$ \\
\hline 13 & 30 & 5.5 & b2150 & D-galactose-binding periplasmic protein ( $m g / B$ ) & 35,690 & 5.68 & 733 & 87 \\
\hline 14 & 30 & 5.5 & $\begin{array}{l}\text { b2310 } \\
\text { b1130 }\end{array}$ & $\begin{array}{l}\text { lysine/arginine/ornithine-binding periplasmic protein (arg } T \text { ) } \\
\text { transcriptional regulatory }(p h o P)\end{array}$ & $\begin{array}{l}28,088 \\
25,519\end{array}$ & $\begin{array}{l}5.62 \\
5.10\end{array}$ & $\begin{array}{l}914 \\
199\end{array}$ & $\begin{array}{l}83 \\
37\end{array}$ \\
\hline 15 & 25 & 7 & b3882 & gamma-hydroxybutyrate dehydrogenase (yihU) & 31,525 & 5.86 & 1293 & 89 \\
\hline
\end{tabular}

